\title{
Developing Guessing Game for Teaching Vocabulary to the Fifth Grade Students of SD Negeri 5 Kubutambahan
}

\author{
Suardiyasa, Komang Gede \\ Ganesha University of Education \\ Suardi yasa@yahoo.co.id
}

\begin{abstract}
This present study was a research and development (R\&D) which concerned in; identifying the kinds of vocabulary were appropriate to be developed as Guessing Game $(\mathrm{GG})$ for teaching vocabulary to the fifth grade of students of SD Negeri 5 Kubutambahan, analyzing the quality of the developed Guessing Game (GG) for teaching vocabulary to the fifth grade of students of SD Negeri 5 Kubutambahan. This study followed the R\&D design proposed by Dick and Carey (2005). This design involves: need analysis, instructional analysis, learner and learning environment, performance objectives, assessment rubric, story board, design and develop, formative evaluation, revision and final product. The subjects of the study were students of fifth grade and the teacher of SD Negeri 5 Kubutambahan. the data were collected through observation, questionnaire, interview, document review and expert judgment. The result of the study shows that: (1) there were four guessing games have been developed with four different themes which were aimed to be used as a media for teaching vocabulary to the first semester of 5 th grade students. Those guessing game were designed based on the criteria of English syllabus of school based curriculum for the first semester of 5th grade students and also based on criteria of educational app by Lee \& Cherner (2015). The final of the guessing game were presented into CD and a manual guide book for teacher. (2) the overall quality of the developed guessing game from the judgment of experts was categorized as excellent (2.73).
\end{abstract}

Keywords: guessing game, vocabulary, fifth grade

\section{Introduction}

From the preliminary observation, the researcher found that most teachers are not able to integrate and provide ICT in teaching and learning process, especially the elementary school teachers. They are not able to create ICT-based media and they still use the traditional method teaching. Designing an interactive media in teaching and learning activity is a very challenging task, especially for the teacher who has no ICT background knowledge. Nowadays because the existence of current technology most of the teachers have been familiar with the use of PowerPoint. PowerPoint is used by the teachers mostly to present the concept of material and to show the series of pictures. Actually the use of PowerPoint can be maximized in form of guessing game.

The existence of current technology brings many positive effects toward the development of teaching media. The use of computers which can operate pictures, audios and videos can help the English teacher to create an innovative game as teaching media to be used for teaching their students. Based on the pre-observation, all of the elementary school in Kubutambahan is equipped by LCD projector. There is no guessing game that used for teaching vocabulary, as we know game is very important teaching media to be used for making young learners have fun when learning vocabulary.

Vocabulary is a very important aspect in language learning which cannot be neglected. Without vocabulary nothing can be conveyed, Thornbury (2002). Therefore, it can be said that vocabulary is the first aspect to be mastered by the learners. Improving young learner's vocabularies will bring many influences to increase their language mastery. Those people whose first isn't English have an even greater need to learn vocabulary and increase their word knowledge. If we learn English as a second language, sufficient number of vocabulary will help us to understand the language and express our thoughts in English. He also stated that to be able to communicate in a language naturally, one should master at least 
2000 words. From the explanation, it cannot be denied that vocabulary has great role in the process of mastering a language.

According to Thornbury (2002), one of the ways that can be done by language teacher to make their students be able to store the new words that they have learned by imaging or visualizing the words. He also adds that language teacher should provide their students with attractive media and easy to interpret pictures for illustrating the meaning of target language vocabulary. Another important aspect that should be taken into account in Teaching English as a Foreign Language (TEFL) is age. According to Harmer (2007), based on their age, learners of EFL can be classified into three different categories there are: Children, Adolescence, and Adult learners. In teaching those three different learners, an English teacher should prepare himself with various teaching strategies. It is because those three types of learners have different needs, competencies, and cognitive abilities. For instance, young learners may learn foreign language better through a game, while adult learners may learn best by interpreting their critical thinking.

There are some reasons why games are good for teaching young learners, those reasons are: (1) Richard-Amato (1988) said that Games can make the students more focus in learning, because they don't feel that they are forced to learn, but learning while playing. (2) Games can lower anxiety, thus making the acquisition of input more likely. (3) Lewis (1999) stated that Games are highly motivating and entertaining, it's also enable learners to acquire new experiences within a foreign language which aren't always possible during a typical lesson. (4) Games can be as media which will give many advantages for the teacher and the students either. (5) The useful of games are attract the students to learn English because it is fun and make them want to have experiment, discover and interaction with the environment. Some expert also figured out characteristic of games that make vocabulary learning effectively. (6) Lee (1996) lists several main benefits when games are used in the classroom, including "a welcome break from the usual routine of the language class", "motivating and challenging", "effort of learning" and "language practice in the various skills". (7) Ersoz (2000) said that games are highly appreciated due to their amusement and interest. Teacher can use games to help their students practice more their skills of communication. To be short, games can be considered useful and effective tools that applied in vocabulary classes. The use of games in teaching vocabulary is a way to make the lesson more interesting, enjoyable and effective.

Based on the explanation above, this study aimed at designing and developing Guessing Game (GG) for teaching vocabulary to the fifth grade of SD Negeri 5 Kubutambahan.

\section{Methods}

The research design used in this research was a research and development. It was used to (1) identify vocabulary that appropriate to develop as guessing game and (2) to measure the quality of the guessing game that being develop. To get the source of the data, the researcher did a document analysis, to analyze the syllabus and lesson plan, administrating questionnaire to the students, interview the English teacher. The researcher did an observation in the classroom.

\section{Findings}

\section{Findings and Discussions}

As stated in previous chapter, this research had two problems. The first one is what kinds of vocabulary were appropriate to be developed as Guessing Game (GG) for teaching vocabulary to the fifth grade of students and the second one is how is the quality of the developed Guessing Game (GG) for teaching vocabulary to the fifth grade of students. 
The first problem was answered by conducting the seven steps of the research and development model by Dick and Carey (2005), namely need analysis, Instructional analysis, learners and learning environment, performance objectives, develop assessment Instruments, develop and design of the product and develop and select material of the product. Need analysis, Instructional analysis, learners and learning environment were done by conducting an observation, interviewing the teacher, questionnaire and analyzing document. Those need analysis was obtained when the researcher did observation in SD Negeri 5 Kubutambahan.

The result of observing the class in the process of learning English showed that there were only few of students who were actively involved during teaching and learning process even in each meeting with different theme, the students who were participate almost the same. The rest of students who were not actively participated during the learning process just calm down without said anything or even asked some question to the teacher. It was hard to know whether they understood or not with the theme that was being discussed. In this case, the teacher gave direct instruction to help students understand the material. Therefore, the teaching and learning process was not running effectively.

The result of interviewing the teacher showed that it was difficult for the teachers to make students actively participated during the learning process, especially in elaboration stage where in this case it was hard to get students asking some questions after given some stimulus in exploration activity. This situation was anticipated by guiding students through exemplified them (i.e. the teacher asked questions first and motivated the students to pose more questions). The researcher found that the teacher never used game as teaching strategy.

After identifying the problem above, the next step was to write performance objectives of this research. which were, to improve learning quality through development of teaching media and to develop guessing game as a media for teaching vocabulary to the first semester of 5th grade students in Kubutambahan. It is because game which were used by the teachers in SD Negeri 5 Kubutambahan was in term of break the ice and none of them had used game as teaching media. So, that is how this research is focus on developing guessing game as a teaching media.

After describing the performance objective, the researchers conducted the next step which was design and develop the product. In designing and developing the product, the researcher considered the English syllabus of the first semester of 5th grade that is used by the English teacher in SD Negeri 5 Kubutambahan. It was done by identifying the distribution of the basic competencies that has to be taught to the first semester of 5th grade students. The result showed that there are twelve basic competencies in the syllabus of the first semester of 5th grade. After that, the researcher identified the theme that should be taught to the first semester of 5th grade students. The result of the identification showed that there were four main themes in the syllabus of the first semester for 5 th grade students. Those are, describing animal, telling time, days and months, daily activities. Then, the next step was drafting the product by making a blue print for guessing game development. It was found that there were four guessing game that were developed. For the product \#1 is the theme of describing animal, product \#2 is telling time, product \#3 is days and months, product \#4 is daily activities. After making the blue print of the product, it was continued by producing the product itself. It was done by considering the mapping of the theme and language focus of the first semester of 5th grade students, and also the objective of the guessing game.

After designing and develop the product, the next step was tested the product through try-out and evaluation questionnaire. It was conducted to know the practicality of the product. First the try-out was conducted twice on the fifth grade of SD Negeri 5 kubutambahan. There were a few tools that required to implement the guessing game, the researcher have to provide LCD projector, sounds and a laptop. After the try-out, the questionnaire was given to the students. There were 5 items that should be answered. 
After the product tested. The next step was measuring the quality of the product in which it was done to answer the second problem of this research which was done through conducted the eighth step of research and development design by Dick and Carey (2005) which are test the product and evaluate testing result.

The rubrics of expert judgment were used in order to measure the product. There were two experts who gave score to those developed guessing game. Both of them are lectures of English Education Department of Ganesha University of Education. There were thirteen criteria of good guessing game for teaching by Lee \& Cherner (2015) namely, (1) Competencies \& Objectives are addressed and use of game enhance student in learning, (2) Content is correct and material relates to the students' real life context, (3) Learning content is appropriate for educational purposes and matched appropriately for student-level and student real-life context, (4) Language used is age appropriate and vocabulary is understandable, (5) Game provides students with skill or knowledge practice and information that help them complete their learning tasks, (6) Activities in Game combine students' learning styles, whether visual, auditory, and/or kinesthetic, (7) Most students can use the Game to create original pieces that represent their learning, (8) Students are able to work in collaborative groups when playing the game with little problem, (9) Topic presented is interesting for students and engaging them in learning, (10) The text, picture and sound presented in Game are in best quality and well-organized, (11) Material follows easy-to-use patterns with nothing to confuse the user, (12) The user guide in an excellent resource in using Game in a lesson and the directions help the user in using the Game, (13) Game presents material and frequently requires students to make decisions, answer questions, or engage in it.

The scale that was used in developing rubric of expert judgment was 1-3, in which 1 means low, 2 medium, and 3 high. The scores given by two experts were analyzed by calculating the mean score of expert judgment for each dimensions as well as the final mean score. The result showed that the mean score of the competencies \& objectives of the developed guessing game was 3.0 and it is categorized as excellent, while the mean score of the content \& material was 2.5 which is belonged to excellent and the experts said that some of the material introduce facts or concepts, not how to use in real life. The mean score of the level of material the developed guessing game was 3.0 and it is categorized as excellent. Then, the mean score of the age-appropriate language of the developed guessing game was 2.0 in which it was categorized as good. The first expert said that some of the clues are too long and not easy for students to guess. While the second expert said that the passive sentences is not appropriate with the student's level, it have to change into active sentences. The mean score of the skill practice of the developed guessing game was 3.0 in which it was categorized as excellent. The mean score of the learning style of the developed guessing game was 3.0 in which it was categorized as excellent. Stimulus creativity of guessing game was given 3.0 mean score and it was belonged to excellent. The mean score of foster collaboration of the developed guessing game was 2.0 and it is belonged to good category. The two experts said that the game mostly focuses students' attention and attract spontaneous answer, therefore no collaboration needed. Interest level and engagement of guessing game was given 3.0 mean score and it was belonged to excellent. Technical quality of guessing game was given 3.0 mean score and it was belonged to excellent. The mean score of the ease of user the developed guessing game was 3.0 in which it was categorized as excellent. The mean score of the user guide \& direction of the developed guessing game was 2.5 in which it was categorized as excellent. The second expert said that there has to be a manual book for the user. The mean score of the content and material of the developed guessing game was 2.5 in which it was categorized. The two experts said that the game tend to encourage students to 
respond immediately. Moreover, the total mean score of the developed guessing game was 2.73 which is belonged to excellent.

After testing the product, the next step was evaluating testing result. In this step, the researcher did a revision to some guessing game based on the comment and suggestions which were given by the experts, the first product that should be revised was the animal in which there were some words that should be changed, it was because those words was too long and confuse the students. Those words are 'this animal is from Australia, it hops and down on its back legs, and it has a pouch' changed into 'this animal is from Australia. It hops up and down on its back legs. It has a pouch'. The second product that should be revised was the months, which there were some words that should be changed. Those words are "the month when you celebrate "imlek" and on the fourteenth day of the month you celebrate valentine day.' Changed into 'the month when you celebrate "imlek". On the fourteenth day of the month, you celebrate valentine day.' The third product that should be revised was horse, which the second clue is in passive sentence 'it is ridden by people' changed into active sentence 'people ride it'.

\section{Discussions}

As other languages, English consists of vocabulary as the basic component of language. Vocabulary is a collection of words in the language which is known, learnt, and used by the speakers (Linse, 2006). Furthermore, vocabulary is the basic component of the language which makes the language becomes so useful for the communications.

Talking about English vocabulary learning in Indonesian primary education, some teachers have implemented two forms into vocabulary learning. Mostly, students do some activities in written and/or in verbal forms. In line with this statement, Kusuma, Adnyani, \& Taharyanti (2017) state that through involving these two forms into some activities, Indonesian students are expected to enhance their English vocabulary mastery which the forms are actually different from Indonesian language (especially in verbal forms). These forms are commonly implemented through the implementation of media such as realia and flashcards since those media are the common media for Indonesian teachers.

Somehow, from the data found, the teacher used direct instruction and made the students got bored during the learning process. The same result was actually been found by Kusuma (2016) where in his study, he found that most elementary teachers used traditional teaching practices which made students bored and got high tension/pressures in learning. Certainly, this was a situation that not every teacher expects to happen. This can be explained, as stated by Clark (1990), Children get bored easily. Children have no choice to attend school. The lack of choice means that class activities need to be fun, interesting and exciting as possible by prepared innovative activities. However, the result of the observation on the class showed that the activity which was done during teaching and learning process just in term of question and answer without using some kinds of media and it was continues in each meeting. It can be said that this teacher used a monotonous teaching strategy in each meeting even they never use any kind of teaching media.

Moreover, from the data gathered, the game is used as ice breaking activity. However, game is one kind of strategy that can be used by the teacher to motivate young learners in making them interested in learning language. Based on Phillips (1997) said that games in the language classroom help children to see learning English as enjoyable and rewarding. Playing games in the classroom develops the ability to cooperate and to compete without being aggressive. According to Allen (1983), games are helpful because they can make students feel that certain words are important and necessary. Without those words, the object of the game cannot be achieved. Therefore, when playing a game the students would concentrate and try to recall words learnt in order to play the game. If games were used more often in the 
classroom, this may help students learn vocabulary faster because the vocabulary is introduced and used in an enjoyable and challenging way.

Therefore, looking at the aforementioned discussion, guessing games were developed. there were four guessing game that were developed. For the product \#1 is the theme of describing animal, product \#2 is telling time, product \#3 is days and months, product \#4 is daily activities. These products then have been tested on its quality by involving content and construct validity and any other test.

\section{Conclusion}

From the findings and discussions, it can be concluded that there were four guessing games have been developed with four different themes which were aimed to be used as a media for teaching vocabulary to the first semester of 5th grade students. Those guessing game were designed based on the criteria of English syllabus of school based curriculum for the first semester of 5th grade students and also based on criteria of educational app by Lee \& Cherner (2015). The final of the guessing game were presented into CD and a manual guide book for teacher. Furthermore, the overall quality of the developed guessing game from the judgment of experts was categorized as excellent.

Considering the conclusions mentioned above, some suggestions were recommended, as the following:

1. It is suggested for the teachers to use these guessing games as a teaching media because the quality of the developed guessing game from the judgment of experts was categorized as excellent.

2. Since the product of this study was prototype guessing game, it might need further improvement. Due to the time availability for data collecting of this study was very short, the researcher did the tried-out in the real teaching-learning process only twice and the quality of the developed guessing games have been tested through the judgment of experts. In order to make the developed guessing game to be optimal, it is suggested for other researchers to continue this study by implementing the developed guessing game in the real teaching-learning process for the whole semester.

\section{References}

Dick, W., Carey L., and Carey J. (2005). The Systematic Design of Instruction. (6th Ed.). Boston: Allyn \& Bacon.

Ersoz, A. (2000). Six games for EFL/ESL Classroom. The Internet TESL Journal, Vol 6(6). Retrieved from http://iteslj.org/Lessons/Ersoz-Games.html

Lee, C.Y, \& Cherner, T.S. (2015). A Comprehensive Evaluation Rubric for Assessing Instructional Apps. Journal of Information Technology Education Research, Vol 14, p.21-53.

Lee, S.K. (1996). Creative Games for the Language Class. Forum, Vol 33(1), p.35. Retrieved from http://exchange.state.gov/forum/vols/vol33/no1/P35.html

Harmer, J. (2007). How to Teach English: An Introduction to the Practice of English Language Teaching. Essex: Pearson Education Limited.

Kusuma, I. P. I. (2016). Developing Reading Material for Elementary Students in Tourism Area by Inserting Local Culture. Journal of English Education and Linguistics Studies (JEELS), 3(1), p. 109-127. 
Kusuma, I.P.I, Adnyani, N.L.D.S, \& Taharyanti, G.A.P. (2017). Developing 10 Interesting Games as Alternatives to the Monotonous Use of Flashcards for Vocabulary Learning and Assessments. Script Journal: Journal of Linguistic and English Teaching. Vol 2 (1). p. 68-82.

Lewis, G. B. (2002). Games for Children. University of Koblenz-Landau: Oxford University Press.

Linse, Caroline. T. (2006). Practical English Language Teaching: Young Learners. Singapore: McGraw Hill Companies, Inc.

Richard-Amato, P. A. (1988). Making it Happen: Interaction in the Second Language Classroom: From Theory to Practice. New York: Longman.

Thornbury, S. (2002). How to Teach Vocabulary. Essex: Pearson Education Limited. 